\title{
The Emerging of New Democratic Space: CSOs and Parliament in Post-Soeharto Indonesia ${ }^{1}$
}

\section{Cornelis Lay}

\begin{abstract}
This article deals with the inclusion of civil society organizations (CSOs) in the decision-making processes in Post-Soeharto era in Indonesia. It argues that reformasi has created and multiplied the democratic space in both the national and local arena. It has not just enlarged the number of CSOs significantly, but also changed the nature of CSOs and has opened the boundary in relations to parliament. This development has confirmed the emerging of the new political space which is more democratic in nature, as witnessed by the present of Gaventa's political space model - "claimed space" as opposed to undemocratic "closed spaces" or "limited space" during the New Order. This paper identifies the presence of a set spaces which is determining the whole course of decision-making processes. This research found the nature of a space, of being either "claimed", "invited" or "closed", is not only determined by who creates the space and able to make use of it within the given boundaries, but also by its relations to other set of spaces, issues in concern, time and infrastructure set up around the spaces.
\end{abstract}

Keywords: CSO; parliament; political space; democracy.

\section{Introduction}

Democratization - or reformasi as most Indonesians prefer to call it, to include decentralization - has its "Pandora Box" effect. The quadruple constitutional reform between 1999 and 2004 which followed reformasi, has not only created "new democratic spaces" (for further discussion on this issue see Cornwall \& Coelho, 2004) at the national level, but also multiplied political spaces in the subnational politics, opening up ways for demos to realize and claim

I would like to express my gratitude to my colleagues at Department of Politics and Government, Faculty of Social and Political Sciences, Universitas Gadjah Mada and to Power, Welfare, \& Democracy Project. Also to Erwin Endaryanta, Longgina Novadona Bayo, Eko Agus Wibisono, and Umi Lestari for their assistance. 
their citizenship rights; and as in many cases (see for example, Heller, 2001) leading to the creation of new political actors. CSOs are among the actors which not only benefited by the presence of these newly created democratic spaces, but also have come to exist due to this democratic opening. As in the case of other Asian countries (Gomez, 1999), Indonesian CSOs have had to contest with other forces to claim space for their political role.

This article is based on my preliminary research on the interlinking between power and space by exploring the relation between civil society organizations and parliament in policy making process in the Post-Soeharto era in Indonesia. Research was conducted over a year, from July 2009 to August 2010; this included five months of field research in Bogor, Jakarta, and Yogyakarta. This paper is part of my paper titled Broken Linkages which was already presented before the Panel on "Indonesian Democracy in Comparative Perspective at Euroseas, Guttenberg, 26-28 August 2010. This article aims to answer the question of to what extent the creation of a new democratic space since 1998 reformation in Indonesia has impact on consolidating democracy in the country.

\section{CSOs in Indonesia: An Overview}

The need to reconstruct a new pattern of state-society relations has triggered the discussion on the role of CSOs in democratization. Most literatures seem to agree that CSOs have been and would remain playing important roles. As "a public ethicalpolitical community of free and equal citizens under a certain legally defined system of rule" as defined in its broader meaning by Cohen \& Arato (1992, p.84) or simply as "subset of social organizations created by the relevant law of particular state" as Weller $(2005$, p.3) puts it, or even in its more instrumentalist definition of "organizations and groups whose activities are directed towards improving, and in more radical sense changing the social and material condition of economically and socially disadvantages" as Eldridge (1989, p.2) defines it, or "as self-organized and autonomous groups and movements" as defined by Lay (1999), CSOs 
have been argued to have a significant role in society and it seems to be continued in the future. However, to what extend and by what means CSOs actually or potentially contribute to democratization remains debatable among experts.

Weller et al. suggested that as institutions or an intermediate world between the family and the state, CSOs somehow contribute to democratization. As he points out, "..., they do democratize in looser sense by broadening the range of voices that can potentially influence political decision" (p.11). Harriss et al. (2004) admitted the presence of CSOs as one of intermediary power between demos and public affairs as implied in Tornquist's (2009) general framework for analysing democracy. However, in assessing the specific over-emphasis of mainstream discourse on the centrality of CSOs as being a condition for the achievement of good governance and successful economic development, they have argued that this line of argument represents "unconstitutional, de-institutionalized and de-politicized democracy" (Harriss et al., 2004, p. 8). While Mietzner (2012), despite his pessimistic view in seeing the future of democracy since 2005-6he describes it as a phenomenon of "stagnation of democracy"still sees the potential of CSOs in preventing the stagnation of democracy from deteriorating into a form of democracy recession.

In the Indonesian context, the current CSOs are both a product of reformasi-most were established during the years of turbulence of 1988 and 2001, and survivors of the past. As noted by Eldridge $(1988,1995,1999)$, since the 1950s there have been a fairly strong emerging of CSOs in the country. Some, survived the authoritarian regime where corporatism exists (for further discussion see King 1977; MacIntyre, 1991), as a specific model of interests intermediation and means of control where "the state plays leading role in structuring and regulating interests, organizing them along the functional rather than class line...., and typically granting official recognition to only one representative body to any given sector" was almost the only game in town (MacIntyre, 1994, p.1). But also, as Sakai (2002) and especially Eldridge argued, they had been able to 
preserve their autonomy without jeopardizing their corporative ties to the state. The ability to keep the balance between autonomy and state co-optation lies in the simple fact that, as in the case of postTotalitarian regime of China (Chan, 2005), CSOs in Indonesia had been able to make use of state fragmentation and of its inconsistent control (Sakai, 2002); and most importantly, to create distinct niches that link a high-quality grassroots' program, activation of regional forum, policy dialog, and joint public advocacy (Eldridge, 1995, 2005).

During the last 10 years or so, more and more CSOs have come to fill the newly democratic political spaces in the post-Soeharto era. Data provided by a long-standing research-based CSO, Institute of Research, Education, and Social Economy Enlightment (Lembaga Penelitian, Pendidikan, dan Penerangan Ekonomi dan Sosial, LP3ES), in 2001 shows that the number of CSOs was only around 426, or a little higher than Jakarta's figure of 412 in $2009 .{ }^{2}$

SMERU publication showed that within a short threeyear period, the number of CSOs have grown tremendously to reach 2,406. The recent figure released by SMERU ${ }^{3}$ in 2004 is 2,646, leading to a higher concentration of CSOs (PLOD, 2006). More importantly, the long spatial concentration of CSOs in the Capital or big cities (Eldridge, 1988, 1989) are now diminishing. As decentralization effectively took place in 2001, some remote provinces such as Papua and Aceh, and even East and West Nusa Tenggara (NTB and NTT) have emerged as the new homes of CSOs. In these provinces, CSO numbers in 2004 were 130, 223, 124 and 136 respectively as compared to 292, 224 and 209 for Jakarta,

2 It is important to note that during the New Order, the number of CSOs were hard to be determined. Hikam (1999) for example provided the number of approximately 7,000 during 1990s. However, as noted by Eldridge (2005), this has to be put into perspective since "the term of 'non-governmental organization' embraces several legal and structural from", and around 70 to $80 \%$ of them are village-based or sub-provincial-based.

3 SMERU is a research institute working on public policy area that was founded as initiatives of Social Monitoring and Early Response Units personnel, a project managed by World Bank as response to financial and political crisis in Indonesia 1998. 
West and East Java. These figures had changed in 2009. In both Aceh and Papua, the numbers declined to 98 and 120, but in NTB and NTT the numbers were higher than before (156 and 162). In 2009, Jakarta-based CSOs had grown dramatically with a slight increase in West Java (255) and slight decrease in Central Java (205) (Smeru). The figures suggested that CSOs are now a nation-wide phenomenon. It is no longer a Java-based phenomenon, let alone Jakarta-based phenomenon.

More than that, there have been very significant changes within the world of CSOs as well as their relationship with the state, especially with parliament. Contrary to the New Order era where there was almost no connection between CSOs and political parties, (Eldridge, 1988, 1989) including those in parliament. Now there is a new tendency of CSO activists to step in and be part of the party, either formally or informally, as demonstrated through the latest case ${ }^{4}$ where some CSO key figures officially joined the government party. At the very least my research found, are serving as strategic partners of the party in policy-making processes.

Apart from that, the nature of CSO activities has also changed. The domination of "charity" type activism of the first

4 Dita Indah Sari, activist of Centre of Indonesia's Labour Movement (Pusat Perjuangan Buruh Indonesia, PPBI) joining National Awakening Party (Partai Kebangkitan Bangsa, $\mathrm{PKB}$ ). She is currently expert staff to the Minister of Labour and Transmigration. Rahlan Nasidik, Executive Director of Imparsial (Indonesian Human Right Monitor that was founded in 2002 to monitor and investigate human right violations), joint Democrat Party (Partai Demokrat) and became spokesperson of the party. Teten Masduki, founder of Indonesian Corruption Watch (ICW) is now became Head of Presidential Office. Based on data from Kompas 2010, Mietzner (2013) suggested there were 7 percent (37 out of 560) members of parliament in 2009, 6 percent candidates for local leaders (governor, mayor or head of district) in 2005 local election were activists of CSOs. Mietzner divided them into three categories based on their background and motivation: First, politicians who previously participated in civil society activism as part of their preparations for further politicial involvement, such as Muhaimin Iskandar. Second group, those who chose civil society as an escape from Soeharto's tight regulation of the political realm. After his fall, however, they, such as Benny Kabur Harman, fully embraced the new democratic system and the opportunities of political participation it offered. Third, reformist activist who crossed over into formal politics because of the deficiencies inherent in Indonesia's postSoeharto 1998 democracy, such as Binny Buchori, Demos (a think tank of democracy and human rights) activist who was joining Golkar (Golongan Karya, Functional Groups) in 2008 and Eva Kusuma Sundari who was joining PDIP (Indonesian Democratic PartyStruggle, Partai Demokrasi Indonesia-Perjuangan). 
generation of 1960s and early 1970s, and of "developmental" type of the second generation of the end of 70s and 80s (Setiawan, 1996; Sinaga, 1993) are playing a lesser role compared to the advocacy type of the new generation CSOs. This development has followed the widening of issues covered. Apart from the traditional issues related to development and participation, new issues have come to the stage. Issues such as governance reform is now a dominant theme of the current CSO activists (Suharko, 2005), along with specific issues related to security sector reform (military, police and intelligence), protection of the weak (women, poor-especially urban poor, consumer, labour, child, etc.); empowering of classbased organized movement or specific groups (labour, peasant and indigenous people for example); and managing resources.

With regards to policy, the role of CSOs has expanded tremendously. Now, they are not only involved in influencing the design and implementation of specific development programs (Eldridge, 1988, 1989), but in designing broader policy measures, and being part of almost the entire policy circle at centre of national space of decision making-parliament, and in many local spaces alike. They have also been able to penetrate into the deeper level of policy making, such as agenda setting. The range of coverage issues are much wider, encompassing local and national places, leading to even larger political spaces for CSOs to engage within.

All of the aforementioned development confirmed the emergence of the new political space which is more democratic in nature as witnessed by the present of Gaventa's "claimed spaces" (Gaventa 1980, 2003, 2006) as opposed to undemocratic "closed spaces" or "limited invited" spaces available during the New Order. Closed or provided space takes place where decision making is undertaken by limited power holders in closed-door meetings without any intention to enlarge the boundaries for inclusion. "Invited space" is a space where varieties of decision-making bodies invite outsiders to take part, either on regular bases or simply on an ad-hoc basis through "one-off consultation" (see also, Cornwall \& Coelho, 
2007, p.1). "Claimed" or "created spaces"—or in Cornwall term, "organic space" emerges out of common concern or identification and may come into being as a result of popular mobilization. It may consist of spaces in which like-minded people join together in common pursuit" (Cornwall, 2002, p.24), or "spaces conquered by civil society demands for inclusion" (Cornwall \& Coelho, 2007, p.:1).

The above development also confirmed the changing nature of CSOs of being more polycentric, implying the end of corporatism and the emerging of a new type of state-CSOs power relations within the new boundaries of more democratic spaces. This dramatic change is not only taking place within the world of CSOs but also in parliament. Its previously inferior constitutional position as rubber stamp of the executive branch has ended. The quadruple constitutional reform has put parliament at the very centre of the policy-making processes. It is now a new space of national politics, locus for policy, budgeting, and oversight processes. The process of forming parliament has also changed. Since the 2004 elections, there has no longer been representation from the military at any level of parliament as MPs chosen through regular free and fair election. The way parliament works has also changed. The bureaucratic type of working is now replaced by a very political one. They no longer solely rely upon government information and expertise in making decision but have gradually moved to decision making based on a combination of party ideological stand points, public opinion, and research finding. They no longer work in an isolated environment, ignoring the voice of the people, but incorporate other social forces, broadening the boundaries for inclusion. In this respect, CSOs are an important source of information and expertise as well as one of the sources of legitimacy for both policy processes and substance.

Despite all the above changes, a comprehensive study on parliament-CSOs relations is rare. Apart from focusing on CSOsstate relations (Sakai, 2002; Eldridge, 2005) as the traditional theme, most recent studies have focused on individual CSOs, mostly to 
assess the impact of certain types of CSO activists to very specific issues such as a better public service, better policy making processes, better access of certain groups to resources and services. In the midst of the tremendous rise in "crafting thesis" of both democratic transition and good governance, most energy has been devoted to capacity-building projects of specific institutions and individuals. While in relation to parliament, most researches focused on the issue of representation, parliament performance, institutional and individual capacity building, and more often, on the level of popular confidence in parliament as most of the survey in the country confirmed. An effort to get a more comprehensive understanding on these complex issues and the interrelation between parliament and CSOs, apart from partial data provided by Demos (2009), is very limited. Such an effort was undertaken by Graduate Program on Decentralization and Local Autonomy (Politik Lokal dan Otonomi Daerah, PLOD), Universitas Gadjah Mada (PLOD, 2006).

PLOD study concludes that despite CSOs experiencing many problems such as weakness in both institutional and individual capacity, and being highly dependent on international donor institutions, the massive presence of CSOs in local areas and their interconnection with parliament have contributed in uplifting the quality of both policy processes and substance, and in paving the way for the wider spread of participation from below. Unfortunately, this collaborative effort involving the Indonesian National Planning Board, United Nations Development Programme (UNDP) and Universitas Gadjah Mada, is a desk study and focused on local place, longing for a field research. It has not yet provided us with enough evidence desperately needed for a more comprehensive conclusion.

\section{Spaces for CSOs Involvement}

As mentioned, reformasi has created the overall environment for the creation of newly democratic spaces, implying the presence of a democratic space of "claimed space" within which people can exercise their right and claim their citizenship. As will be discussed in 
great detail in the following sections, despite the presence of a wider democratic space in parliament, all three continuum dimensions of spaces-"closed-space", "invited-space", and "claimed-space" are simultaneously working in determining the whole course of political decision making processes. All of them delimit the field of what is possible for CSOs that have been on the side-lines of policy processes for years, and for the MPs as well.

\section{"Claimed-Space"}

Our resource persons from both parliament and CSOs testified that in principle, all CSO activists as well as individuals are eligible and have the right to engage in policy processes. The reasons as well as the mechanisms to enter parliamentary forum are varied. However, consultation is the most common argument that legitimate CSO activists and public-at-large seek to have access to parliament meeting without any restriction. Through consultation, individuals and CSOs can present themselves in parliamentary forum either voluntarily or by invitation. In both cases, their presence has been used as sources of information by MPs in making decisions.

There are two reasons for the presence of this "claimedspace": legal and political. As for legal reasons, the regulation stipulates that all meetings are opened to the public and requires the involvement of civil society as an integral part of policy processes. The normative argument behind this is related to the basic idea of democracy-people have the right to be involved in public matters and have the right to know, and of good governance, especially in relations to the need for transparency and accountability. The legislature on creating bills clearly states that every single draft of the bill has to have an academic draft as a basis for discussion. This mandatory requirement gives no room for MPs and government to avoid CSO activist engagement. At the very least both parties have to formally accommodate the presence of CSOs, including people from university and research centres.

Permadi (Interview, October 14, 2009) confirmed that in 
every single meeting, the Commission always allotted time and space to meet CSO activists and individuals for public consultancy. ${ }^{5}$ Normally the administration section of the Commission is asked either to invite relevant CSOs, including experts from universities and research centres to attend public hearing or to ask relevant individuals or institutions to organize meetings with MPs during their working tour to local areas (Ali, Marjuki., interview, October 29, 2009). ${ }^{6}$

The involvement of CSO activists are not merely based on invitation. In many cases the CSO activists are also eager to find ways to enter into the parliament forum. CSOs are also actively taking initiative (Karmila, D., interview, October 24, 2009; Hamid, U., Interview, October 4,2009$).{ }^{7}$ In some cases, the CSOs make the proposals through formal letters, followed by communication with individual MPs who, according to their assessment, can help them to be present and be in the centre of parliamentary meetings. However, in some other cases, the CSOs attempt to find their way into parliamentary meeting through dramatic means. Permadi said that in his long experience communicating with CSO activists, he was often confronted with short messages aggravating the danger of specific articles formulated in a draft of a bill, prompting the involvement of the CSOs or activists. Permadi shared that in some of the instances, he too shared the worry of the CSOs. But in other instances, he disagrees with the CSOs since he has his own views on such the issues. ${ }^{8}$

Permadi, MP of Commission I, 2004-2009; Commission dealing with defence and international affairs Interview in Jakarta.

6 Ibid; Marjuki Ali, Speaker of the House for 2009 - 2014, interview in Jakarta.

7 Dian Karmila, Network Coordinator of Syarikat Indonesia, Yogyakarta; Usman Hamid, Executive Director of KontraS (Komisi untuk Orang Hilang dan Korban Kekerasan, Commission for Missing Persons and Victims of Violence), interview in Bogor.

$8 \mathrm{He}$, for example has a different opinion in relation to Indonesian military position. For him it is important to strengthen the Indonesian National Armed Force (Tentara Nasional Indonesia, TNI) to be the strongest military force in Asia just like in Soekarno's era. This position contrasts to CSO activists' who tend to see the development of TNI as a treat to democratic process. 
As for political reasons, all resource persons from parliament are confident that civil society involvement in policy processes is good in itself for two important reasons: to strengthen the legitimacy of both policy products and their position as MPs (Ali.,M, interview, Ibid; Sutrisno, T., interview, November 21, 2009; Nursuhud, interview, November 20, 2009; Safawi, Z., interview, November 21, 2009). ${ }^{9}$ As one MP said, "it is an effective political tool to make pressure to other fraction and government" (Sundari, E.K., interview, October 13, 2009). ${ }^{10}$

In the case of drawing the Bill on Pornography, Eva Kusuma Sundari (interview, ibid) for example said that without pressure both in parliament and in the street from CSO, the content of the law would be even worse. ${ }^{11}$ She related that "the pressure from the CSO has proven to be very effective to make significant changes in Law on Pornography". The law itself is far from perfect in her eyes. However, the experience of working together with CSOs was highly useful since it not only provided her with political support, but also academic argument which was desperately needed. Her position was confirmed by Rieke Dyah Pitaloka (interview, October 12, 2009), an artiste and women activist-turned politician. As she confessed that collaboration with individual MPs allowed her to understand the latest developments in Parliament. She achieved through what she termed as "man marking" approach, or using physical meetings, emails, phone calls and letters. She then used this understanding to determine issues and slogans for her street demonstrations, and to draw up documents to be surrendered to Parliament. In this way, she was able to persuade not only MPs and government officers, but also key

9 Tuti Sutrisno, MP from National Mandate Party (Partai Amanat Nasional, PAN), interview in Jakarta; Nursuhud, interview in Jakarta; Zuber Safawi, from the Prosperous Justice Party (Partai Keadilan Sejahtera, PKS) interview in Jakarta.

10 Eva K Sundari, a member of parliament, interview in Jakarta.

11 Interview, Ibid. 
figures in society. ${ }^{12}$ Pitaloka's experience is very common among CSO activists.

Some MPs believe that the massive involvement of the public in the process of passing bills demonstrates parliament's attempts to maximize its institutional capacity in the policy processes (Mihati, interview, October 27, 2009, December 18, 2009). ${ }^{13}$ However, not all MPs agree that the change in CSO-MP relations has come about as a result of change in the way Parliament works. Some MPs testified that there is neither any clear institutional mechanism which sets out how parliament should involve people in its work; nor any guidelines from party headquarters. This alternative view suggests that CSO involvement mostly results from the willingness of individual MPs to engage with them (Susilo, D., interview, December 1, 2009). ${ }^{14}$

\section{"Closed-Space" Within "Claimed-Space"}

The overall creation of new democratic spaces is not automatically paving way for "claimed spaces" to fully materialize. There is a set of spaces within the broader democratic space in parliament that remains closed. As both MPs and CSOs activists confirmed, not all stages of policy processes are free for public attendance. Except for plenary session, a closed-door meeting is a norm and regular part of the game at some stages of policy processes. However, it requires a strong argument, and procedurally requires an anonymous agreement amongst MPs at their meetings.

But some other phases, such as "Drafting team meeting"-the final stage before a draft of law is brought to plenary session, for example-there is no need to have an anonymous agreement since it has been a closed-door meeting since the beginning, giving no room

12 Rieke Dyah Pitaloka, former anti-porn bill activist, who was elected as MP from PDIP, 2009-2014, interview in Jakarta.

13 Mihati, interview in Jakarta and Yogyakarta.

14 Djoko Susilo of PAN, Yogyakarta. He is currently Indonesian Ambassador to Austria. 
for the public, including CSOs to be involved. Despite the impact of the CSOs, the reason for the exclusion is because the meetings are very technocratic in nature. At that stage, the focus is to only deal with very technical and legal matters, and not political ones. So, the argument goes, there is no necessity to have public scrutiny since all the substance have been agreed upon by all parties involved. However, as some expert teams of parliament suggested, the process of "wording" of an article at this stage sometimes changes the entire logic of the law.

In another case, as demonstrated through the process of making law on Special Status of Aceh, the closed-door meeting was due to political reasons (Hamid, F., interview, October 23, 2009; Budiman, H., interview, October 24, 2009; Syahrizal, T.B., interview, October 15, 2009). ${ }^{15}$ As confirmed, "the debates on crucial articles such as on human right court, truth and reconciliation commission, local political party, independent candidate for local governor/ mayor/ head of regency, Islamic law, authority of national and local government, and sharing of revenue which are have very serious political implication were mostly discussed behind closed-door". ${ }^{16}$

This case seems to suggest that the nature of "space" of being "closed, invited, or claimed", is not only shaped by who created it and the capability of actors to make use of it, but also by the nature of the issues concerned.

Lobby is the most important "closed space" identified within the broader democratic space. My observation during the long and tiring debate on the issue of "Century Gate"17

15 Farhan Hamid, the People's Consultative Assembly (Majelis Permusyawaratan Rakyat, MPR) vice chairman, 2009-2014, former MP representing Aceh, interview in Jakarta; Hendra Budiman, AJMI (Aceh Judicial Monitoring Institute) Director and member of JDA (Jaringan Demokrasi Aceh, Aceh Democracy Network), interview in Jakarta; Teuku B. Syahrizal form Aceh Civil Society Task Force (ACSTF), interview in Jakarta.

16 Focus Group Discussion with activists on Aceh, Jakarta, October 15, 2009.

17 Century gate case emerges from Bank Indonesia policy on short term funding facility for Century Bank, about 6,7 trillion rupiahs. President Susilo Bambang Yudhoyono, BI (Bank Indonesia, the Central bank of Republik Indonesia), and Finance Minister Sri 
early this year demonstrated that lobbying can take both informal and formal forms. As an informal space, it has been part of Indonesian parliament tradition since the very beginning, practicing as forum to establish a common middle ground on certain issues among competing parties before a formal meeting takes place. But as a formal space, it is new, taking place after reformasi that has formally been integrated into the parliament mechanism to settle disputes on specific issues or agenda, and even between individuals, among parties, and between parties and government. As most of my resource persons testified, since lobby has proven to be an effective means to resolve disputes, it has now become prominent, changing its nature from an ad-hoc to an "omnipresent" type of space. It is now replicated itself within all spaces of policy making available in parliament, leaving aside the very question of transparency and accountability. More importantly since lobbying involves only very limited-strategic and highly profile issues, it plays an important political role in determining the whole course of policy processes and substance.

Some activists and MPs suggested that despite lobby providing no room for non-party's people to be physically present and formally being part of the processes, it does not necessarily mean that CSOs people cannot intervene. They still can channel their views through their informal link with individual MPs that happened to be part of a lobby. Sending short messages is the most common way exercised by CSOs to present themselves in this closed space. However, since lobby is normally taking place in a very short and tense time, as most MPs said, instead of looking into such short messages, they make use of it to consult their top party leaders. The "Century Gate" case confirmed that lobbying is a critical time and space where "the real decision makers" step in to make their final decision. In such a way, it provides an effective channel for the working of both the second 
and the third dimensions of power (for further discussion on the faces of power see Gaventa, 1980; Lukes, 2005).

Lobby is closed space not only for CSOs activists but "ordinary MPs" as well. Only very limited MPs are eligible to enter to this space, especially those who hold formal positions, leading to an even higher competition among MPs to have official position in both parliament and parties. I found that lobbying is a necessary evil. As a purely political instrument to prevent dead-lock in decision making processes, lobby has proven to be an effective tool. However, it is also a powerful mechanism of exclusion. This finding suggests that even within a "broader claimed space" that is assumed to be democratic in nature there is a possibility of a set of non-democratic "closed places" to materialize.

\section{"Semi-closed-semi-invited-spaces"}

This study also found the presence of what might be called "semi-closed-semi-invited spaces" where "identities" play critical roles as password for inclusion. Some sub-committee meetings are technically open to public. However, not every single CSO and individual can attend them. Only very limited invited individuals and CSOs are eligible, leading to a kind of "elite settlement" type of engagement. This kind of "arbitrary representation" guaranteed small numbers of CSOs activists to have access to an even deeper public policy arena. However, to be eligible to this kind of privilege, individual or activists it is required to demonstrate certain kinds of "identities". As Dian Sari suggested, a well-established-networkCSO has more voice to be heard than those with no clear-cut constituency and networking. They are most likely to be the one that Parliament would give priority (Sari, D.K, interview, 12 October 2009). ${ }^{18}$

Apart from that, as demonstrates through the case of Propatria

18 Dian K. Sari, INFID (International NGO Forum on Indonesian Development) Deputy Director, interview in Jakarta. 
which has privilege in relation to SSR related issues, CSOs with outstanding record on the issues of concern would also get priority. While this has potential to divide CSOs as some activists argued, this somehow has a positive impact. It serves as an incentive structure for CSOs to manage themselves in such a way so as to be eligible as a reliable partner of parliament. In most cases, closeness to MPs and party is the most important "identity" that an individual or CSOs members have to have. On the one hand this has forced CSOs activists to build capacity to negotiate and communicate with MPs and party official, while on the other it provides "middle ground" for consensus building, softening political as well ideological stands of both sides. However, this "middle way", often created tension within CSOs as it has been interpreted as compromising CSOs principles by some activists.

Apart from developing a trusted full relationship, some CSOs equipped itself with an image of being close to key figures in government office, be it a minister, military commanders, police chief, or even the President to uplift their bargaining position in the eyes of MPs. Others use their international network to level their position with MPs (Marut, D.K., interview, August 28, 2009. ${ }^{19}$

The case of making Law on Environment demonstrated the effectiveness of this path in creating a kind of "semi-closedsemi-invited space" for CSOs to penetrate into even deeper level of policy processes (Barry, interview, October 14, 2009). ${ }^{20}$ It is also true for the case of Propatria in making law on State Defence and on TNI. As members of its working group said, most of

19 Phone interview with Don K. Marut, Executive Director of INFID.

20 Walhi and its network, Natural Resources Management proposed the change of the law by discussing it with Department of Health before surrendered to parliament. After several meetings, they came to agree that the Department would take an active role in drafting a bill supported by environment activists. Walhi then used it to establish communication with strategic MP figures such as Sony Keraf, former Minister of Environment and Catur from PAN. Their communication encouraged MPs to use their initiative right to propose a draft of bill, which was realized through the creation of a small team called "drafting team" within parliament (Barry, Director of WALHI [Wahana Lingkungan Hidup Indonesia, The Indonesian Environmental Forum] interview in Jakarta). 
their time and energies were spent to convince many competing and fragmenting groups within the executive branch and military camp as an important step to convince parliament that such regulations were needed. As they said, only after the Minister and key military figures within the department as well as within the military headquarters showed their support, parliament started to open the forum to Propatria (Widjayanto, A., and Keliat, M., interview, August 12 and 13, 2009; Anggoro, K., and Bhakti, I.N., interview, August 14, 2009; Prasetyo, E., interview, August 15, 2009). ${ }^{21}$ The same pattern was also true for the case of making law on Police. CSO such as Ridep and Concern could only make their way to parliament after high-rank police officers gave signal of "approval" (Keliat, M., interview, August 12 and 13 2009; Sulistyo, H., interview, October 4 and November 3, 2009; Moena, R., interview, November 2, 2009). ${ }^{22}$ While these cases seem to suggest different ways through which CSOs can penetrate even deeper into the policy arena, from a broader perspective these underline the persistence of unequal power relation between parliament and government, implying the persistence of hidden power, within the boundaries of new democratic space. Regardless of constitutional reform legally transferring decision-making power to the parliament, as in the past, the executive branch, military, and the police retain its important positions as sources of political legitimacy in the eyes of MPs. The executive branch, military and the police seem to have power to repress issues from not being transformed into agenda setting. These cases also question "the democratic transition" arguments on the centrality of constitutional and institutional reforms as well as proper regulations as key ingredients for the accomplishment of

21 Andi Widjayanto and Makmur Keliat, interview in Jakarta; Kusnanto Anggoro and Ikrar Nusa Bhakti, interview in Jakarta; Eddy Prasetyo, interview in Jakarta.

22 Makmur Keliat former Executive Director of Ridep (Research Institute for Democracy and Peace), interview in Jakarta, August 12 and 13 2009; Hermawan Sulistyo, former Executive Director of Ridep, now Director of Concern Strategic Think Tank (a think tank dealing with securities issues), interview in Bogor and Jakarta; and Riefki Moena, Former Director of Ridep, interview in Jakarta. 
democratic transition. It seems that all of these "crafting" institutions do not automatically lead to the transformation of power relations in favour of democratic principles.

There is another way through which CSOs create this "semiclosed-semi-invited space" so as permit them into even deeper policy area - that is by taking initiative to have an informal-limited meeting with MPs and his/her expert team to discuss specific issues. For example, Centre for Indonesia Risk Studies (CIRiS) during the of making the law on Gas and Mining invited one of the key MP, Arifin and his fellow expert to share information. This August 2008 meeting allowed CIRiS to get a clearer picture on some critical issues, then make use of them to draft a policy brief passed to MPs (Anggoro, K., and Endrayana, E., interview, August 10, 2009). ${ }^{23}$

This research found that in most cases MPs and CSOs activists preferred to follow this path instead of having a more formalinstitutionalized type of meeting. Apart from being more effective in exchanging information and views, as most resources persons argued, at the very least this kind of linkage is needed in earlier stages, functioning as transitory steps into a more formalized and institutionalized type of engagement (Prihantono, H., interview, October 15, 2009). ${ }^{24}$ For the interest of individual CSOs, there is no doubt this kind of "space" is useful since it allows CSOs not only to have closer individual-based linkage with individuals, but also helps both sides to get clear picture of issues in concern. We would not know to what extent this was going to contribute to the democratization processes, but it seems that this case reconfirms both Eldridge and Nordholt findings on the great overlap of formal and informal structures as well of individual and institution in Indonesian politics.

23 CIRiS: 2008; Kusnanto Anggoro, CIRiS Director Executive and Erwin Endrayana, CIRiS expert, interview in Jakarta.

24 Hari Prihantono, Director Executive of ProPatria (a nonprofit organization that working on three issues: security sector, community based development, and cultural and education reform), interview in Jakarta. 


\section{Concluding Remarks: A Reflection}

Our discussion so far has demonstrated that reformasi in Indonesia has created and multiplied new democratic spaces at both national and local places. Judging from their overt faces, the presence of these new democratic places has both broadened the political boundaries for inclusion where excluded people of the past have more room to exercise and claim their citizenship rights, and it has changed the nature of power relations between the state and the society as a whole, implying the emerging of more democratic linkages between demos and public affairs.

As I have argued, contrary to the authoritarian period of the New Order, today's CSOs have enjoyed political privileges of being part in the entire circle of policy processes. They have even been able to penetrate into deeper policy arena-agenda setting, pushing this "closed space" of the past to migrate to other edges of space continuum - "claimed space" of decision making. Viewed form a technocratic perspective, the involvement of CSOs are also important in legitimizing the processes and-as they have been able introduce research-or evidence-based policy into the processes, in strengthening the quality of the policy.

It is also true that the presence of new democratic spaces has changed the entire worlds of both civil and political societies as demonstrated through the dramatic change within the worlds of CSOs and parliament, and the world that interlinks the two. CSOs have been able to claim their political role as intermediary power between demos and public affairs, changing the very nature of their previous limited role as advocates of demos. They are now living in the world of civil and political society alike. As for CSOs, parliament has also enjoyed a formal political role of being the prime locus of policy-making. Parliament is no longer functioning as a rubber stamp. Legally speaking, it is the real decision-making institution. The interlinking between the two has also changed. The "mutually disinterested" nature of CSOs-parliament relation in the past is now over as the political linkages between the two become more 
intensive, leading to even more complex power relations between them.

However, it would be a misleading to conclude that Indonesia is now on the march toward democratization as proponents of "wave of democracy" of Huntington (1991) would argue, or has reached the stage of "democratic transition" as argued by Linz and Stepan (1996, 1998). As our discussion suggested, democratic potential is there. But the 12 years of reformasi marked by a massive instalment of liberal democratic institutions together with massive dispersion of power and political liberalization - as observed by Dhakidae (1998) and Lay (1998) in the early stage of Indonesian democratization, is still "a long and winding road" and "an uphill battle", far from being closed to both the ideas of "deepening democracy" of Fung and Wright (2003) and of substantive democracy of Harriss et al. (2005). It is even far from the idea of "participatory democracy" as has been argued elsewhere by Gaventa, Cornwall, and many others, unless for a limited number of CSO activists.

This is so because, despite all of the above-mentioned changes, my research seems to suggest that even within the boundaries of "claimed space" that are assumed to be democratic in nature, the presence of a set of either "semi-closed-semi-invited spaces" or even "closed spaces" is very obvious. The reasons vary-starting from the very technical one as demonstrated through the case of "drafting team meeting" up to the very political one as in the case of making bill on Special Status of Aceh and of lobbying, the bottom line is the same: the effectiveness of the working of hidden and invisible power in determining the whole course of policies processes. It is a result as well as a reflection of unequal balance of power among actors where the old power remains the sources for political legitimacy.

This research also found that the nature of a space of being "claimed", "invited" or "closed" is not only determined by who creates and the ability to make use of it within the given boundaries, but also by its relation to other set of spaces, issues in concern, and - while I did not display the data, time and infrastructure set up 
around the spaces. As the case has shown, despite parliament having constitutionally been guaranteed to possess decision-making power, it still very much depends on other sets of spaces-ministerial office, military headquarter and lobby, in making decisions. In the future, it seems that the presence of this set of undemocratic spaces would be even more dangerous for democracy since there is a strong tendency of these "closed-spaces" to find their own niches to replicate themselves, leading to a possibility of being omnipresent, and are gradually being institutionalized within the wider democratic space. 


\section{References}

Chan, Kin-Man. (2005). The Development of NGOs under a PostTotalitarian Regime: the Case of China. In Weller, Robert P. (ed.), Civil Life, Globalization, and Political Change in Asia (pp. 20-41). London and New York: Routledge.

Cohen, J.L., \& Arato, A. (1992). Civil Society and Political Theory. Cambridge: MIT Press.

Cornwall, A., \& Coelho, V. S. P. (2004). New Democratic Spaces? In Cornwall, A and Coelho, V. S. P. (Eds.). IDS Bulletin, 35 (2), pp.110.

Cornwall, A. \& Coelho, V. S. P. (2007). Space for Change? The Politics of Participation in New Democratic Arenas. In Cornwall, A and Coelho, V. S. P. (eds.), Spaces for Change? The Politics of Participation in New Democratic Arenas. Zed books.

Eldridge, P. (1988). Non-Governmental Organisations and The Role of The State in Indonesia. Paper presented at The State and Civil Society in Contemporary Indonesia, Centre of Southeast Asian Studies/ Department of Indonesian and Chinese Studies, Monash University, $25-27$ November.

Eldridge, P. (1989). NGOs in Indonesia: Popular Movement or Arm of Government?. (Working Paper 55). Monash University: Centre of Southeast Asian Studies.

Eldridge, P. (1995). Non-Governmental Organization and Democratic Participation in Indonesia. Kuala Lumpur: Oxford University Press.

Eldridge, P. (2005). Nongovernmental Organizations and Democratic Transition in Indonesia. In Weller, Robert P., (ed.), Civil Life, Globalization, and Political Change in Asia (pp. 148-170). London and New York: Routledge.

Gaventa, J. (1980). Power and Powerlessness: Quiescence and Rebellion in an Appalachian Valley. Chicago: University of Illinois Press.

Gaventa, J. (2003). Towards Participatory Local Governance: Assessing the Transformative Possibilities. Paper prepared for the Conference on Participation: From Tyranny to Transformation", Manchester, 27-28 February.

Gaventa, J. (2006). Finding the Spaces for Change: A Power Analysis, IDS Bulletin, 37. 22-33.

Gomez, J. (1999). Contest for Space: Civil and Political Society in East and Southeast Asia. Paper presented at the $13^{\text {th }}$ Asia Pacific Roundtable, organized by the Institute of Strategic and International Studies under the Auspices of the Asean-ISIS network, Kuala Lumpur, 31 May - 3 June.

Harriss, J., Stokke, K., \& Törnquist, O. (eds.). (2004). Politicising Democracy: 
The New Local Politics of Democratisation. Houndmills: Palgrave.

Heller, P. (2001). Moving the State: The Politics of Democratic Decentralization in Kerala, South Africa, and Porto Alegre. Politics \& Society, 29 (I). 131-163.

Hikam, AS. (1999). Demokrasi and Civil Society. Jakarta: LP3ES.

Huntington, S.P. (1991). Third Wave: Democratization in the Late of Twentieth Century. Norman, Oklahoma and London: University of Oklahoma Press.

King, D. (1977). Authoritarian Rule and State Corporatism in Indonesia. Paper presented at the Annual Meeting of the American Political Science Association, Washington, 1 - 4 September.

Lay, C. (1998). Political Transition in Indonesia: Problems and Opportunities. Paper presented at The Relation Between the European Union and Indonesia in the Context of the Asian Crisis, held by The Clingendael Institute, 26 - 27 October, The Hague, The Netherlands.

Lay, C. (1999). Prospect of Civil Society in Indonesia, Paper presented at National Workshop on Indonesian in Transition Toward Democracy, held by Lembaga Studi Agama dan Filsafat (LSAF), 14 April, Jakarta.

Lay, C. (2010). Broken Linkages: A Preliminary Study on Parliament Linkages in Indonesia. Paper presented at Indonesian Democracy in Comparative Perspective panel discussion held by Euroseas, 2628 August, Guttenberg.

Linz, J.J., \& Stepan, A.C. (1996). Problems of Democratic Transition and Consolidation: Southern Europe, South America, and Post-Communist Europe. Baltimore, MD: John Hopkins University Press.

Linz, J.J., \& Stepan, A.C. (1998). Defining and Crafting Democratic Transition, Constitution and Consolidation. Paper presented at the International Seminar on Toward Structural Reforms for Democratization in Indonesia: Problems and Prospects, held by LIPI and the Ford Foundation, 12 - 14 August.

Lukes, S. (2005). Power: Radical View, Second Edition. London: Palgrave Macmillan.

MacIntyre, A. (1991). Business and Politics in Indonesia. Sydney: Allen \& Unwin.

MacIntyre, A. (1994). Organizing Interest: Corporatism in Indonesian Politics. (Working Paper, No. 43), Asia Research Center, Murdoch University, August.

Mietzner, M. (2012). Fighting the Hellhounds: Pro-democracy Activists and Party Politics in Post-Suharto, Indonesia, Journal of Contemporary Asia, 43(1), 28-50. 
Mietzner, M. (2013). Indonesia's Democratic Stagnation: Anti-Reformist Elites and Resilient Civil Society. Jurnal Democratization, 19 (2), 209-229.

PLOD UGM. (2006). Public Engagement in Decentralization: A Case Study on Problems, Dynamics and Prospect of Civil Society Organizations in Indonesia (Unpublished Report). Yogyakarta.

Sakai, Y. (2002). Flexible NGOs vs. Inconsistent State Control. In Shigotomi, Shinichi. (Ed.), The State and NGOs: Perspective from Asia (pp.161-177). Singapore: Institute for Southeast Asian Studies.

Samadhi, W.P., \& Warouw, N. (eds.). (2009). Democracy Building on the Sand (Demokrasi di Atas Pasir). Yogyakarta: PCD and Demos.

Savirani, A \& Törnquist, O. (eds.). (2015). Reclaiming the State: Overcoming Problems of Democracy in Post-Soeharto Indonesia. Yogyakarta: Polgov \& PCD.

Sinaga, K. (1993). An Assessment of the Role and Development of NGOs in Indonesia: Aiding Poor People's Movements or Becoming the 'Long Arm' of the Powerful? (Unpublished Doctoral Dissertation). Bielefeld: University of Bielefeld.

Setiawan, B. (1996). Non-Governmental Organization and Civil Society. Prisma 7 July, pp 35-61.

Suharko. (2005). Building Democracy: The Relation between Government, CSO and Democratic Governance (1966-2001). Yogyakarta: Tiara Wacana. 